\title{
Pemanfaatan Media Pembelajaran Interaktif bagi Guru Pendidikan Agama Islam di Era Milenial
}

\author{
Halimah", Vina Aini Salsabila, Nia Kurniawati \\ Program Studi Pendidikan Bahasa Inggris, Fakultas Keguruan dan Ilmu Pendidikan, Universitas Suryakancana, \\ Cianjur, Indonesia \\ *Corresponding Author \\ Jl. Dr. Muwardi Pasir Gede Raya Cianjur \\ E-mail: halimahdata.2021@gmail.com

$\begin{array}{llll}\text { Received: } & \text { Revised: } & \text { Accepted: } & \text { Published: } \\ \text { 29 July 2021 } & \text { 21 October 2021 } & \text { 17 November 2021 27 November 2021 }\end{array}$

\begin{abstract}
Abstrak
Pelaksanaan kegiatan pelatihan yang dilaksanakan pada tanggal 22 Juni 2021 di Auditorium Gedung Guru Cugenang, Cianjur, Jawa Barat ini memiliki dua tujuan yaitu 1) untuk mengenalkan dan menggunakan beberapa media pembelajaran digital interaktif dan 2) untuk mengintegrasian media ajar digital dan model belajar yang dapat menumbuhkan $4 \mathrm{C}$ yang dilaksnakan selama satu hari setara dengan 5 jam pelajaran. Metode yang digunakan dalam pelatihan ini adalah 1) tahap persiapan, 2) tahap pelaksanaan, serta 3) tahap evaluasi dan pelaporan. Berdasarkan kegiatan pelatihan yang telah dilaksanakan maka dapat dipahami beberapa hal. Pertama, pelatihan ini efektif dalam meningkatkan pengetahuan dan memotivasi dosen untuk memahami dan melaksanakan kewajibannya tidak hanya dalam aspek pengajaran tetapi juga mulai menggeliatkan kegiatan di bidang penelitian dan pengabdian kepada masyarakat. Kedua, pelatihan ini merupakan salah satu praktik nyata pembelajaran bagi mahasiswa yang terlibat dalam kegiatan dan memberi mereka pengalaman kegiatan kemsyarakatan. Mahasiswa tidak hanya dibekali pengetahuan namun juga dibimbing untuk mengimplemnetasikan di masyarakat. Ketiga, bagi guru khususnya guru PAI pelatihan ini dapat meningkatkan pengetahuan dan memotivasi guru untuk senantiasa mengembangkan kompetensinya sehingga guru dapat merancang dan menyajikan sebuah pembelajaran yang efektif dan kreatif yang mengarahkan siswa untuk memiliki kemampuan pendidikan Abad 21 yaitu kemampuan berpikir kritis, berkolaborasi, berkomunikasi dan berkreasi.
\end{abstract}

Kata kunci: Guru Agama Islam; Media Interaktif; Pelatihan Milenial

\begin{abstract}
The training activity, which was held on June 22, 2021 at the Auditorium of the Cugenang Teacher Building in Cianjur, West Java, had two objectives: 1) to introduce and use several interactive digital learning media, and 2) to integrate digital teaching media and learning models that can foster 4C. The training activity was carried out in one day, which is equivalent to 5 hours of lessons. The methods used in this training are 1) the preparation stage, 2) the implementation stage, and 3) the evaluation and reporting stage. Several things can be deduced from the training activities that have been completed. For starters, this training is effective in increasing knowledge and motivating lecturers to understand and carry out their responsibilities not only in the teaching aspect, but also in beginning to expand activities in the fields of research and community service. Second, this training is one of the genuine learning practices for students who participate in activities and gain experience in community activities. Students are not only given knowledge, but they are also shown how to apply it in the community. Third, this training can increase knowledge and
\end{abstract}


Indonesian Journal of Community Services

Volume 3, No. 2, November 2021

http://jurnal.unissula.ac.id/index.php/ijocs

DOI: http://dx.doi.org/10.30659/ijocs.3.2.161-173

\begin{abstract}
motivate teachers to constantly develop their competencies. Therefore, teachers can design and present effective and creative learning that directs students to have 21st Century educational skills, such as the ability to think critically, collaborate, communicate, and be creative.
\end{abstract}

Keywords: Islamic education teachers; interactive media; millennial training

\title{
PENDAHULUAN
}

Kegiatan pelatihan pemanfaatan media pembelajaran interaktif untuk guru Pendidikan Agama Islam yang dilakukan kepada masyarakat merupakan kegiatan darma perguruan tinggi sebagai pengejawantahan misi Tri Dharma Perguruan Tinggi; pendidikan, penelitian dan pengabdian kepada masyarakat. Ketiga hal ini harus dijalankan secara seimbang. Aktivitas civitas akademika perguruan tinggi berlandaskan Tri Dharma perguruan tinggi harus terus disesuaikan mengikuti tuntutan, perkembangan dan kebutuhan zaman. Perkembangan IPTEK serta perubahan lingkungan dengan segala dampaknya, mengharuskan institusi perguruan tinggi untuk lebih mengembangkan diri dalam upaya pelaksanaan Tri Dharma Perguruan Tinggi dengan menciptakan dan meningkatkan budaya akademik, terutama dilingkungan kampus agar kompetensi savitan akademika dapat diandalkan sesuai bidangnya. Dosen sebagai aktor Tri Dharma PT diharapkan agar selalu menyesuaikan program-programnya dengan perkembangan zaman, serta lebih mengembangkan budaya akademik agar produktivitas dan kontribusinya bermanfaat dalam masyarakat (Lian, 2019; Gunawan et al., 2015).

Pengabdian dalam Tri Dharma Perguruan Tinggi merupakan salah satu peran secara aktif positif perguruan tinggi yang diembankan kepada dosen, mahasiswa dan civitas akademika perguruan tinggi (Shee, 2018) dalam memecahkan permasalahan (problem solver) yang dihadapi masyarakat dengan menghasilkan ilmu yang siap pakai, dalam arti penemu masalah (problem finder) melalui penelitian (Fathurrahman \& Muhtarom, 2019) yang dapat digunakan untuk menerangkan (to explain), meramalkan (to predict) dan diterapkan (to practice) dalam kehidupan masyarakat, dunia usaha dan dunia industri (Yuliawati, 2012).

Seperti yang telah diungkapkan bahwa pelaksanaan Tri Dharma Perguruan Tinggi harus dilaksanakan dengan menyesuaikan perubahan, perkembangan, dan kebutuhan jaman. Karena kebutuhan akan berubah seiring dengan perkembangan dan perubahan zaman. Saat ini manusia berada di zaman globalisasi teknologi 4.0. Artinya segala bentuk kegiatan Tri Dharma Perguruan Tinggi harus menyesuaikan dengan karakteristik dan kebutuhan di zaman 4.0. Ditambah lagi sekarang manusia hidup di tengah Pandemi Covid ini, terdapat banyak perubahan yang terjadi, tak terkecuali di bidang pendidikan. Perubahan terbesar yang dirasakan adalah perlunya meningkatkan literasi digital bagi seluruh peserta pendidikan. Hal ini pun berkaitan dengan tuntutan revolusi industri yang telah digaungkan jauh sebelum pandemi berlangsung, yakni tuntutan penguasaan teknologi informasi dan komunikasi di bidang pendidikan.

Akan tetapi, harapan penguasaan teknologi bagi guru menghadapi beragam tantangan sebagaimana yang telah dibahas para ahli, seperti: 1) guru enggan melakukan perubahan dalam melaksanakan kegiatan pembelajaran, 2) waktu guru yang tersedia untuk mempersiapkan pembelajaran yang menggunakan teknologi sangat terbatas, 3) akses guru terhadap berbagai sumber informasi masih terbatas, 4) pelatihan guru di bidang pemanfaatan teknologi untuk pembelajaran masih terbatas dan belum merata hingga ke derah, dan 5) dukungan teknis dan aturan pemanfaatan teknologi untuk pembelajaran masih belum jelas (Siahaan, 2015). Bagi peserta didik, masalah yang dihadapi adalah biaya, motivasi belajar, layanan, umpan balik, kurangnya pengalaman serta kebiasaan (Attri, 2012). Pembelajaran jarak jauh dinilai tidak lebih baik dari pembelajaran yang dilakukan secara langsung atau tatap muka (Fojtík, 2018). Kurangnya interaksi yang efektif, minimnya pengorganisasian merupakan salah satu yang 
menjadi kendala pembelajaran jarak jauh, pembelajaran jarak jauh yang efektif tentu harus didukung dengan konten yang diberikan, fasilitas koneksi internet serta perhatian dan ketersediaan yang cukup besar (Buselic, 2012).

Menanggapi hal tersebut, perlu dilakukan peningkatan pengetahuan dan keterampilan guru agar pelaksanaan pembelajaran berbasis teknologi dapat terlaksana. Salah satu hal yang harus diperhatikan adalah penggunaan media pembelajaran digital interaktif dalam pembelajaran. Media berdasarkan asal katanya dari bahasa Latin, medium, yang berarti perantara. Media oleh karenanya dapat diartikan sebagai perantara antara pengirim informasi yang berfungsi sebagai sumber atau resources dan penerima informasi atau receiver. Dalam proses belajar, media berperan dalam menjembatani proses penyampaian dan pengiriman pesan dan informasi. Dengan menggunakan media dan teknologi, proses penyampaian pean dan informasi antara pengirim dan penerima akan dapat berlangsung dengan efektif (Pribadi, 2017).

Terkait pentingnya pemanfaatan media pembelajaran, maka perlu dilakukan peningkatan kemampuan guru dalam menguasai media pembelajaran tidak hanya berbasis digital namun juga mampu mengakomodir kemampuan komunikasi, kolaborasi, berpikir kritis dan kreatif. Maka dari itu, kegiatan ini mencoba fokus pada pemanfaatan media digital interaktif dalam pembelajaran.

Untuk itu Program Studi Pendidikan Bahasa Inggris Fakultas Keguruan dan Ilmu pendidikan (FKIP) Universitas Suryakancana Cianjur memiliki visi untuk mewujudkan program studi yang unggul, terdepan, dan terpercaya dalam bidang Ilmu pendidikan bahasa Inggris, serta menanamkan nilai-nilai kearifan lokal dan bermartabat. Untuk mewujudkan visi tersebut program studi Pendidikan Bahasa Inggris mempunyai misi diantaranya menyelenggarakan pendidikan dan pengajaran bahasa Inggris secara profesional dan menjalin kerjasama dengan pihak terkait baik tingkat nasional, regional dan internasional.

Sejalan dengan itu untuk menjawab tuntutan Tri Dharma Perguruan Tinggi yang didukung Undang-Undang No. 12 Tahun 2012 tentang Pendidikan Tinggi (UU Dikti) bahwa perguruan tinggi yang ada di Indonesia tidak boleh membeda-bedakan antara bidang pendidikan, penelitian dan pengabdian masyarakat. Maka program studi bahasa Inggris merasa perlu untuk turut serta dalam pembinaan kemampuan bahasa Inggris terhadap masyarakat.

Sebagai bagian dari LPTK (Lembaga Pelatihan Tenaga Kependidikan), Prodi Pendidikan Bahasa Inggris FKIP Unsur merasa terpanggil untuk ikut memperbaiki kualitas pendidikan bahasa Inggris di kabupaten Cianjur terutama kualitas para pengajarnya. Seperti yang selama ini kita ketahui bahwa kualitas para pengajar bahasa Inggris di berbagai wilayah termasuk Cianjur cukup memprihatinkan. Hal ini karena kurangnya motivasi dan juga terbatasnya media untuk mengembangkan kompetensi para guru setelah mereka lulus dari LPTK.

Seperti yang telah diungkapkan sebelumnya bahwa permasalahan yang dihadapi oleh guru adalah kurang dalam keterampilan dan penguasaaan teknologi khususnya teknologi informasi dan komunikasi, kurangnya kreativitas guru dalam memvariasikan teknik pengajaran, belum digunakannya media ajar digital dalam pengajaran, belum dikuasainya konsep Higher Order Skills 'Four Cs' (HOS4C) yaitu: (1) Creativity, (2) Critical thinking, (3) Communication, (4) Collaboration atau disingkat dengan $4 \mathrm{C}$, dan kurang motivasi dalam mengikuti pelatihan. Maka dari itu kegiatan pengabdian ini akan berusaha memberikan solusi yang dihadapi oleh mitra dengan mengacu pada pendapat para ahli.

Kegiatan pelatihan pemanfaatan media pembelajaran interaktif untuk guru Pendidikan Agama Islam merupakan salah satu solusi yang ditawarkan oleh tim pengabdian kepada masyarakat Program Studi Pendidikan Bahasa Inggris Fakultas Keguruan dan Ilmu Pendidikan Universitas Suryakancana Cianjur sebagai langkah untuk mensinergikan upaya pemerintah dalam meningkatkan profesioalisme guru. Diantara Berbagai upaya telah dilaksanakan oleh pemerintah antara lain dalam rangka peningkatan mutu dan profesionalisme guru PAI yang muaranya adalah peningkatan mutu pembelajaran di kelas, upaya tersebut antara lain ikut serta dalam pendidikan dan pelatihan (Lubis, 2017), seminar dan program sertifikasi guru (Sakti, 2020). 
Dalam kegiatan ini tim pengabdian memberikan pelatihan kepada guru khususnya guru PAI dengan tujuan agar guru PAI senantiasa dapat menjalankan tugasnya secara profesional di zaman 4.0 ini (Masitoh, 2017). Adapun pelatihan meliputi 1) Pengenalan dan penggunaan beberapa media pembelajaran digital interaktif dan 2) Pengintegrasian media ajar digital dan model belajar yang dapat menumbuhkan $4 \mathrm{C}$.

Tugas guru sebagai profesi meliputi mendidik, mengajar dan melatih. Mendidik berarti meneruskan dan mengembangkan nilai- nilai hidup/kepribadian (Sepriyanti, 2012). Mengajar berarti meneruskan dan mengembangkan ilmu pengetahuan dan teknologi. Sedangkan melatih berarti mengembangkan keterampilan-keterampilan kepada peserta didik (Darmadi, 2015). Selain itu, peran guru juga sebagai mediator, dimana guru hendaknya memiliki pengetahuan dan pemahaman yang cukup tentang media pendidikan, karena media pendidikan merupakan alat komunikasi untuk lebih mengefektifkan proses belajar-mengajar. Media pembelajaran merupakan sarana yang sangat urgen dan merupakan bagian integral demi berhasilnya proses pendidikan dan pengajaran di sekolah. Guru tidak cukup memiliki pengetahuan tentang media pendidikan dan pembelajaran, tetapi juga harus memiliki keterampilan memilih menggunakan serta mengusahakan media pembelajaran yang baik (Dudung, 2010).

Guru PAI adalah pendidikan profesional yang memiliki tugas memberi pemahaman materi agama Islam kepada peserta didik dan masyarakat. Guru PAI setidaknyaa memiliki dua tugas yaitu tugas melaksanakan sebagai pendidik dan pengajar di sekolah dan juga memiliki tugas memberikan pemahaman materi agama Islam kepada peserta didik agar peserta didik dan masyarakat memiliki cara pandang atau pemahaman terhadap agama (Al qur'an dan hadis) secara tepat yang ditandai dengan sikap dan perilaku yang santun, damai serta anti kekerasan. Guru PAI yang profesional setidaknya memiliki tiga misi yaitu; Misi dakwah Islam. Mampu menunjukkan dan memahamkan Islam kepada siapapun yang ada di muka bumi ini. Misi pedagogiek. Mampu melakukan proses pembelajaran yang ideal. Mampu membimbing dan membina etika dan kepribadian peserta didik saat di sekolah ataupun diluar sekolah. Profil guru yang mampu dijadikan contoh (uswah) bagi peserta didik dan masyarakat merupakan peran penting dalam mensukseskan misi edukasi bagi guru (Muchith, 2016).

Guru Pendidikan Agama Islam (PAI) secara generik tertuang dalam Standar Kompetensi Guru (Permen no. 16 tahun 2007). Kompetensi guru tersebut semula disusun secara utuh, namun pada akhir proses peresmiannya menjadi peraturan menteri, diklasifikasikan ke dalam 4 kategori kompetensi dengan judul seperti tertera pada Peraturan Pemerintah Nomor 19 tahun 2005 tentang Standar Nasional Pendidikan. Kompetensi inti guru Pendidikan Agama Islam (PAI) dijabarkan sebagai berikut: Pertama, kompetensi pedagogik. Kompetensi ini meliputi : a) penguasaan terhadap berbagai karakteristik peserta didik dari aspek fisik, moral, sosial, kultural, emosional, dan intelektual, b) penguasaan terhadap berbagai teori belajar dan prinsip-prinsip pembelajaran yang mendidik, c) menguasai kurikulum yang terkait dengan bidang pengembangan yang diampu, d) memiliki keterampilan dalam melakukan kegiatan pengembangan yang mendidik, e) dapat memanfaatkan teknologi informasi dan komunikasi untuk kepentingan penyelenggaraan kegiatan pengembangan yang mendidik, f) memfasilitasi pengembangan potensi peserta didik untuk mengaktualisasikan berbagai penguasaan teknologi (Nasir, 2013).

Para ahli mendefinisikan guru adalah "Pendidik adalah tenaga kependidikan yang berkualifikasi sebagai guru, dosen, konselor, pamong belajar, widyaiswara, tutor, instruktur, fasilitator, dan sebutan lain yang sesuai dengan kekhususannya serta berpartisipasi dalam menyelenggarakan pendidikan (Sepriyanti, 2012). Sedangkan guru professional adala guru yang mempunyai kemampuan mengorganisir materi ajar, sumber media pembelajaran, membuat skenario pembelajaran sehingga tingkat kedalaman materi dapat direlevansikan dengan karakteristik peserta didik (Umah, 2015), mengusai sebuah kurikulum yang sudah diterapakan, dan mampu membuat rancangan pembelajaran yang sistematis dengan menetapkan metode apa yang digunakan atau dengan apa media apa untuk menyampaikan metode tersebut (Fajriana \& 
Aliyah, 2019), profesi guru perlu dikembangkan secara terus menerus dan proporsional sesuai tuntutan jabatan fungsional guru. Terlebih guru-guru di madrasah, sangat perlu meningkatkan profesionalitasnya dan kreativitasnya, dalam menghadapi perkembangan ilmu pengetahuan dan tekhnologi, supaya madrasah keberadaannya di dunia modern masih diperhitungkan, karena madrasah merupakan salah satu solusi membekali peserta didik yang berimbang antara ilmu agama, dan ilmu umum (Amin, 2019), Peningkatan kualitas kinerja guru harus selalu diupayakan, salah satunya melalui penilaian kualitas guru (Ubabuddin, 2018), yang seharusnya seorang guru profesional itu harus mengembangkan kompetensi- kompetensinya agar mutu pendidikan di tiap sekolah tidak rendah dan prestasi anak didikpun dalam belajar bisa meningkat (Nurkholisah, 2017).

\section{METODE PELAKSANAAN}

Kegiatan pelatihan ini dilaksanakan pada tanggal 22 Juni 2021 di Auditorium Gedung Guru Cugenang, Cianjur, Jawa Barat. Penyelenggara kegiatan adalah dosen dan mahasiswa dari Program Studi Pendidikan Bahasa Inggris Universitas Suryakancana berkolaborasi dengan Lembaga Pendidikan Bahasa Inggris English Sky Bridge Cianjur, Jawa Barat.

Kegiatan pengabdian dikemas dalam acara pelatihan dengan tema "Pelatihan Pemanfaatan Multimedia Pembelajaran Interaktif". Kegiatan pengabdian ini mengadaptasi langkah-langkah pengabdian dari para ahli yang terdiri dari tahap persiapan, tahap pelaksanaan serta tahap evaluasi dan pelaporan (Gunawan et al., 2015); (Paridi, Sudika, \& Burhanuddin, 2018); (Sukri, Rusdiawan, Nawawi, \& Burhanuddin, 2018); (Burhanuddin, Intiana, Sunayu, Saharuddin, \& Rahmat, 2013); (Iswati, 2019) seperti yang ditampilkan pada Gambar 1.

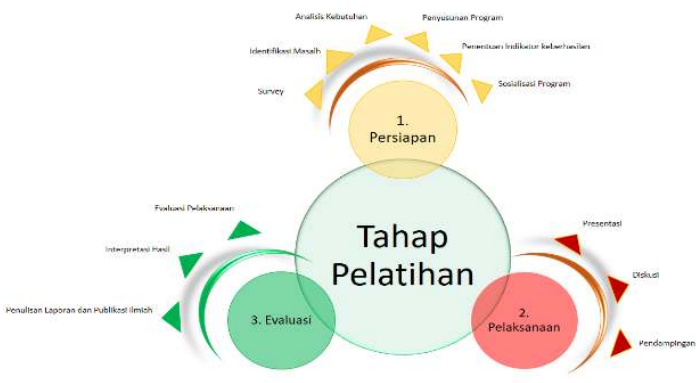

Gambar 1. Metodologi Pelatihan

\section{Tahap Persiapan terdiri dari:}

a. Survey Awal

Tahap pertama dalam kegiatan pengabdian ini adalah melakukan survey yang bertujuan untuk menentukan participan dalam kegiatan pelatihan. Penentuan participan ini dilakukan untuk menentukan langkah selanjutnya yaitu yang berkenaan dengan kegiatan identifikasi masalah.

b. Identifikasi Masalah

Pada tahap ini dilakukan identifikasi terhadap permasalahan yang ada. Seperti yang telah diungkapkan sebelumnya bahwa permasalahan yang dihadapi oleh guru adalah kurangnya keterampilan dalam penguasaaan teknologi khususnya teknologi informasi dan komunikasi, kurangnya kreativitas guru dalam memvariasikan teknik pengajaran, belum digunakannya media ajar digital dalam pengajaran, belum dikuasainya konsep Higher Order Skills 'Four Cs' (HOS4C) yaitu: (1) Creativity, (2) Critical thinking, (3) Communication, (4) Collaboration atau disingkat dengan $4 \mathrm{C}$, dan kurangnya motivasi dalam mengikuti pelatihan.

c. Analisis Kebutuhan 
Setelah masalah diidentifikasi langkah selanjunya adalah melakukan pre-test, wawancara, atau memberikan kuisioner kepada partisipan. Kegiatan ini bertujuan untuk menggali data tentang harapan yang mereka dapatkan dari pelatihan.

d. Penyusunan Program

Setelah melakukan tahap analisis kebutuhan, tahap selanjutnya adalah menyusun program yang terdiri dari rencana kegiatan yang akan dilaksanakan selama pelatihan. Kegiatan terdiri dari: presentasi, Tanya jawab, dan pendampingan.

e. Perumusan Indikator Keberhasilan

Indikator keberhasilan dapat dilihat dari:

a) Peserta memahami konsep dasar guru professional.

b) Peserta memahami berbagai macam media pembelajaran interaktif yang dapat digunakan dalam pembelajaran

c) Peserta mampu mengoperasaikan langkah-langkah penggunaan media pembelajaran interaktif.

f. Sosialisasi Program

Sosialisasi program merupakan tahapan menyampaikan maksud dan tujuan dilaksanakannya kegiatan kepada masyarakat yang tela ditunjuk sebagai calon partisipan kegiatan.

\section{Tahap Pelaksanaan}

Pelaksanaan program dilaksanakan berdasarkan jadwal program yang sudah direncanakan sebelumnya. Program dilaksankan dalam tiga tahap; Presentasi, diskusi dan tanya jawab, dan pendampingan.

a. Presentasi

Pelaksanaan program dilaksanakan berdasarkan jadwal program yang sudah direncanakan sebelumnya. Program dilaksankan dalam tiga tahap; Presentasi, diskusi dan tanya jawab, dan pendampingan.

b. Diskusi dan Tanya Jawab, dilaksanakan setelah tahap presentasi.

c. Pendampingan

Pendampingan dilakukan selama proses kegiatan. Pendamping mendampingi peserta untuk membantu ketika terjadi kendala selama pelatihan.

\section{Tahap Evaluasi}

a. Evaluasi Pelaksanaan

Evaluasi merupakan bagian yang penting di dalam kegiatan ini, karena tahap ini adalah kegiatan mengamati secara seksama pelaksanaan kegiatan. Hasil pengamatan tersebut menjadi sebuah landasan untuk keputusan tindak lanjut yang diperlukan.

\section{b. Interpretasi Hasil}

Hasil evaluasi pelaksaan kemudian dinterpretasi dan disusun menjadi laporan pelaksanaan kegiatan

\section{c. Penulisan Laporan Akhir}

Tahap ini merupakan tahap yang terakhir di dalam penelitian ini. Laporan akhir disusun setelah jangka waktu program yang sudah direncanakan yang bertujuan untuk menyatakan bahwa seluruh kegiatan atau program selesai dilaksanakan. Tahap evaluasi terdiri dari dua kegiatan; Evaluasi pelaksanaan dan interpretasi hasil dan penyusunan laporan dan artikel ilmiah

\section{HASIL DAN PEMBAHASAN}

Kegiatan pengabdian kepada masyarakat ini diselenggarakan dan dikemas dalam bentuk seminar dan pelatihan dengan judul "Pelatihan Pemanfaatan Media Pembelajaran Interaktif bagi Guru PAI" dilaksanakan pada hari Selasa, 22 Juni 2021. Peserta kegiatan ini adalah guru PAI Sekolah Dasar se-Wilyah Kecamatan Cugenang Kabupaten Cianjur Provinsi Jawa Barat (Gambar 1). 
Kegiatan ini dihadiri oleh peserta berjumlah 16 orang dan panitia berjumlah 12 orang. Kegiatan pelatihan berlangsung selama satu hari mulai pukul 07.00 hingga 16.00 WIB atau setara dengan 5 jam pelajaran dengan susunan acara terlihat pada Tabel 1 dengan mengikuti tiga tahapan pelatihan, yaitu penyajian materi, Tanya jawab, dan pendampingan. Hasil pelaksanaan pelatihan ini selengkapnya desripsikan sebagai berikut.

\section{Penyajian Materi}

\begin{tabular}{|c|c|c|c|c|}
\hline No. & Acara & Waktu & Tempat & $\begin{array}{l}\text { Penanggung } \\
\text { Jawab/Pemateri }\end{array}$ \\
\hline 1. & Registrasi Ulang & $07.00-08.00$ & $\begin{array}{l}\text { Gedung PGRI Kec. } \\
\text { Cugenang }\end{array}$ & Mahasiswa \\
\hline 2. & Upacara Pembukaan & $08.00-09.00$ & $\begin{array}{l}\text { Gedung PGRI Kec. } \\
\text { Cugenang }\end{array}$ & \\
\hline 3. & Coffee Break & $09.00-09.30$ & $\begin{array}{l}\text { Gedung PGRI Kec. } \\
\text { Cugenang }\end{array}$ & \\
\hline \multirow[t]{5}{*}{4.} & Seminar dan pelatihan & & & \\
\hline & $\begin{array}{l}\text { Sesi 1: Revolusi Industri } 4.0 \\
\text { dan Pendidikan }\end{array}$ & $09.30-10.00$ & $\begin{array}{l}\text { Gedung PGRI Kec. } \\
\text { Cugenang }\end{array}$ & $\begin{array}{l}\text { Dr. Halimah, S.Pd., } \\
\text { M.Pd. } \\
\text { Nia Kurniawati, } \\
\text { S.Pd., M.Pd., }\end{array}$ \\
\hline & Sesi 2: Media Ajar & $10.00-11.00$ & $\begin{array}{l}\text { Gedung PGRI Kec. } \\
\text { Cugenang }\end{array}$ & $\begin{array}{l}\text { Vina Nurviani, S.Pd., } \\
\text { M.Pd., } \\
\text { Asep Saepulloh, S.S, } \\
\text { M.Pd. }\end{array}$ \\
\hline & Sesi 3: Pengenalan QR Code & $11.00-11.30$ & $\begin{array}{l}\text { Gedung PGRI Kec. } \\
\text { Cugenang }\end{array}$ & Anisa Sofarini, M.Sc. \\
\hline & Sesi 4: Pengenalan Padlet & $11.30-12.00$ & $\begin{array}{l}\text { Gedung PGRI Kec. } \\
\text { Cugenang }\end{array}$ & $\begin{array}{l}\text { Vina Aini Salsabila, } \\
\text { M.Pd. } \\
\text { Muhammad Fachmi } \\
\text { Imanuddin, S.Pd. }\end{array}$ \\
\hline 5. & ISHOMA & $12.00-13.00$ & $\begin{array}{l}\text { Gedung PGRI Kec. } \\
\text { Cugenang }\end{array}$ & Mahasiswa \\
\hline \multirow[t]{2}{*}{6.} & $\begin{array}{l}\text { Seminar dan Lokakarya } \\
\text { Sesi 3: Pengenalan Padlet } \\
\text { dalam pembelajaran }\end{array}$ & $13.15-13.45$ & $\begin{array}{l}\text { Gedung PGRI Kec. } \\
\text { Cugenang }\end{array}$ & $\begin{array}{l}\text { Dr. Jauhar Helmie, } \\
\text { M.Hum. dan Asep } \\
\text { Saepuloh, S.S., M.Pd. }\end{array}$ \\
\hline & $\begin{array}{l}\text { Sesi 4: Pengenalan } \\
\text { Bookwodget dalam } \\
\text { pembelajaran }\end{array}$ & $13.45-15.30$ & $\begin{array}{l}\text { Gedung PGRI Kec. } \\
\text { Cugenang }\end{array}$ & $\begin{array}{l}\text { Elis Homsini } \\
\text { Maolida, S.Pd., } \\
\text { M.Pd., dan } \\
\text { Vina Nurviyani, S.S. } \\
\text { M.Pd. }\end{array}$ \\
\hline 9. & Penutupan & $15.30-16.00$ & $\begin{array}{l}\text { Gedung PGRI Kec. } \\
\text { Cugenang }\end{array}$ & Mahasiswa \\
\hline
\end{tabular}

Kegiatan pelatihan ini menghadirkan empat pemateri dari Lembaga Pendidikan Sky Bridge dan FKIP Universitas Suryakancana, yaitu 1) Nia Kurniawati, 2) Nurul Novtiani Sari, 3) Fuzi Fauziyah, dan 4) Muhammad Fachmi Imanuddin.

Nia Kurniawati pada sesi ini memaparkan tentang bagaimana menjadi seorang guru PAI yang professional di Abad 21. Dalam pemaparan tersebut beliau menyampaikan bahwa menjadi seorang guru PAI di Abad 21 yang professional adalah seorang guru harus memahami konsep Pendidikan dan Pembelajaran Pembelajaran dalam era revolusi industri yaitu pemanfaatan teknologi digital dalam proses pembelajaran (Gambar 2). Guru dituntut untuk bisa beradaptasi dengan zaman, harus mampu menguasai teknologi agar dapat menyesuaikan dengan peserta 
Indonesian Journal of Community Services

Volume 3, No. 2, November 2021

http://jurnal.unissula.ac.id/index.php/ijocs

DOI: http://dx.doi.org/10.30659/ijocs.3.2.161-173

didik, mampu memanfaatkan teknologi informasi untuk meningkatkan kualitas proses belajar mengajar sehingga siswa memiliki keterampilan 4C Creativity, Critical Thinking, Collaboration, Communication. Selama materi disampaikan peserta diperbolehkan untuk menanya secara langsung.

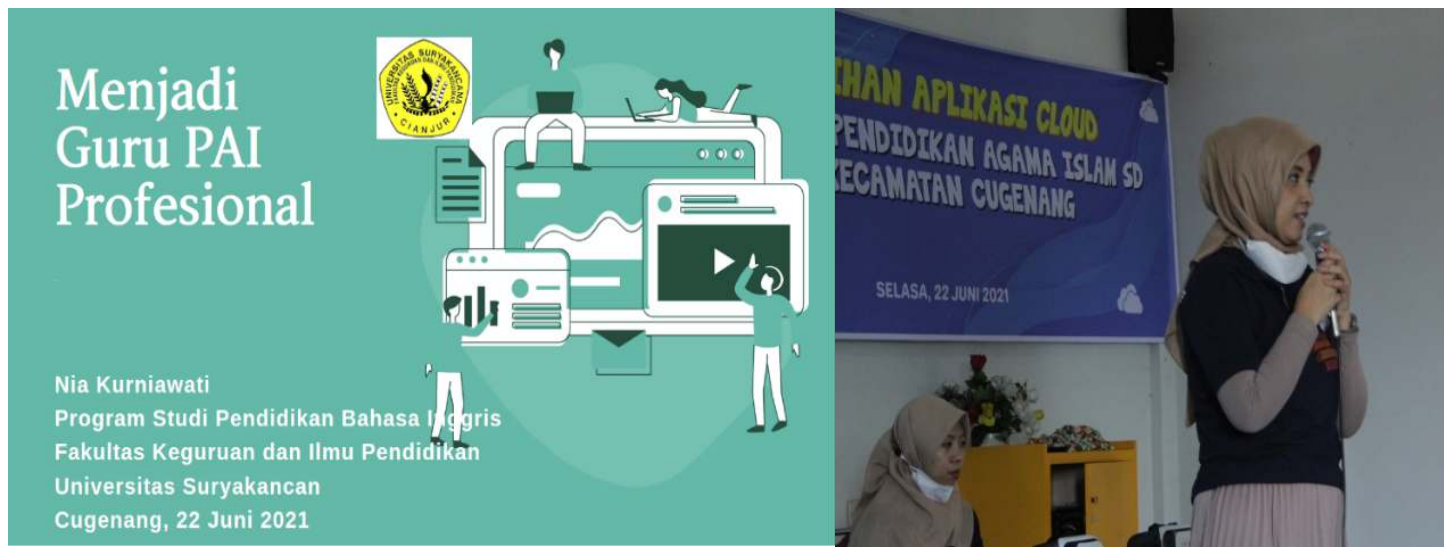

Gambar 2. Presentasi oleh Ibu Nia Kurniawati

Pemateri kedua, Nurul Novtiani Sari dan pemateri ketiga, Fuzi Fauziah, menyampaikan materi tentang penggunaan media pembelajaran interaktif yang dapat digunakan dalam pembelajaran ilmu Tajwid. Media tersebut beruba aplikasi yang dapat diunduh pada perangkat android dan tidak berbayar, serta dapat digunakan secara offline. Aplikasi tersebut bernama "Bookwidgets" (Gambar. 3). BookWidgets merupakan website yang digunakan untuk mengembangkan bahan ajar agar lebih interactive. BookWidgets menyediakan berbagai fitur, seperti test, ulasan materi pelajaran, permainan, matematika, dan survey. Aplikasi ini juga dapat digunakan untuk mengevaluasi siswa (Gambar 3).

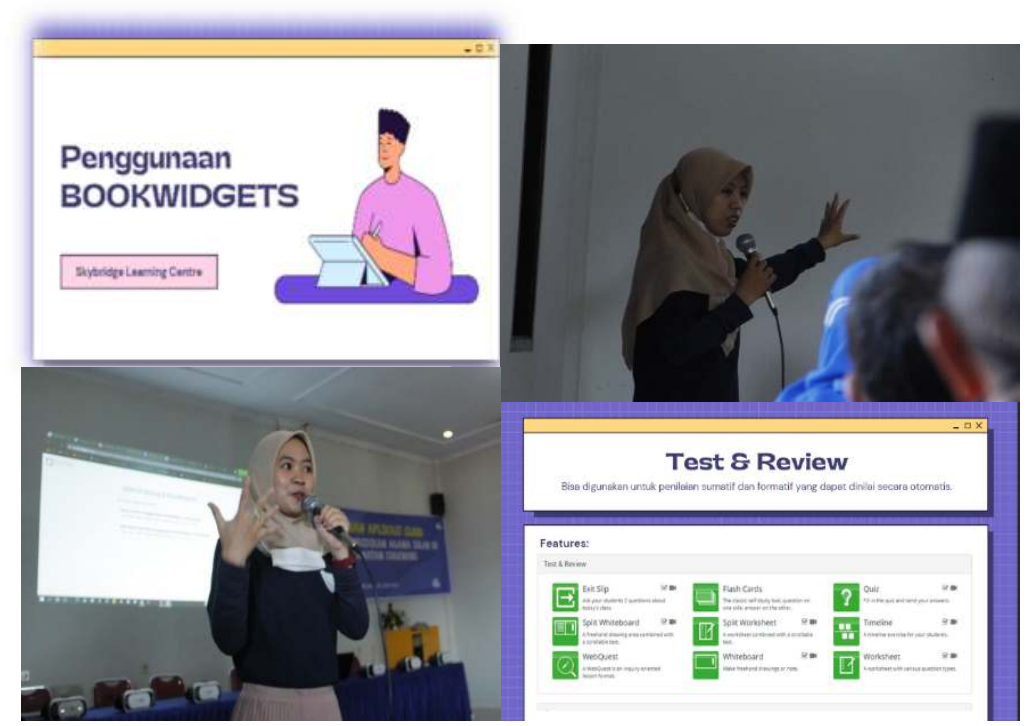

Gambar 3 Presentasi oleh Fuzi Fauziah dan Nurul Novtianti 
Pemateri keempat adalah Muhammad Fachmi Imanuddin. Dalam pemaparannya, dia membawakan materi tentang aplikasi Padlet dalam pembelajaran (Gambar 4). Banyak platform pembelajaran daring yang digunakan guru selama melaksanakan pembelajaran daring seperti Edmodo, Google Classroom, WA, Zoom Cloud Meeting, Google Meet dan Padlet. Setiap platform pembelajaran daring memiliki kelebihan dan kekurangan. Dalam kondisi saat ini, pilihan platform pembelajaran daring bukan mencari satu yang terbaik namun mencari satu yang paling mungkin dilaksanakan sesuai dengan kondisi di sekolah masing-masing. Demikian juga dengan platform pembelajaran daring Padlet. Padlet adalah salah satu aplikasi Web 2.0 yang saat ini sedang booming selain Blendspace, Slideshare, Voki, Storybird dan lain-lain (Haris et al., 2017).

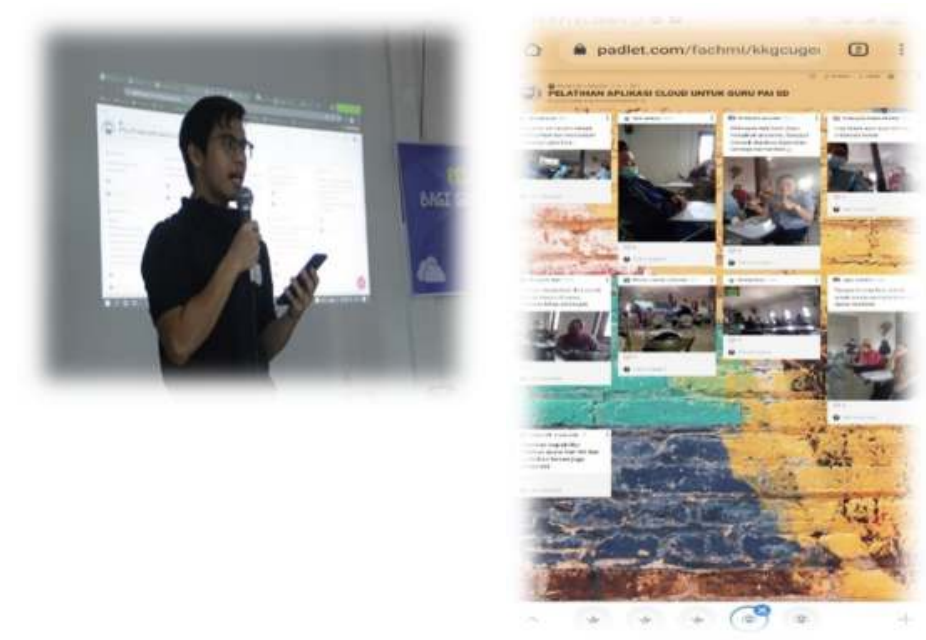

Gambar 4. Penyampaian materi tentang aplikasi Padlet dalam pembelajaran

Padlet adalah platform pembelajaran daring yang bisa disebut sebagai platform pembelajaran daring sinkron karena pendidik dan peserta didik hadir secara bersama pada jam yang sama. Secara sederhana, padlet bisa disebut sebagai papan tulis online yang memungkinkan pendidik dan peserta didik menyampaikan dan membagikan ide-ide/gagasan dan pemikiran baik dalam bentuk teks, foto maupun video. Padlet ini sangat mudah digunakan karena tidak perlu mengunduh aplikasi tertentu dan fitur-fiturnya mudah dipelajari. Selain itu, padlet bisa dioperasikan melalui smartphone, tablet, laptop dan komputer. Pengguna bisa memilih padlet versi gratis atau versi berbayar sekitar 40an ribu rupiah/bulan.

\section{Sesi Tanya Jawab}

Setelah dilaksanakan sesi penyampaian materi, selanjutnya adala sesi Tanya Jawab. Pada sesi diskusi dan tanya jawab para peserta sangat antusias. Sesi diskusi dan tanya jawab dibuka sampai tiga sesi dengan penanya masing-masing sesi sebanyak tiga orang. Para peserta banyak yang bertanya tentang bagamana solusi terhadap penggnaan aplikasi di daerah yang sulit terdapat internet.

\section{Sesi Pembimbingan/Praktik}

Kegiatan terakhir dari pelatihan ini adalah pendampingan pelatihan penggunaan beberapa aplikasi yang sudah dipelajari. Pada sesi ini peserta mempraktikkan menggunakan multimedia yang data digunakan dalam pembelajaran. Kegiatan ini terdiri dari langkah-langkah berikut:

a) Peserta mempersiapkan mobile phone.

b) Peserta dibimbing untuk mengunduh aplikasi dari mobile phone.

c) Peserta dibimbing untuk melakukan registrasi pada aplikasi yang digunakan. 
Indonesian Journal of Community Services

Volume 3, No. 2, November 2021

http://jurnal.unissula.ac.id/index.php/ijocs

DOI: http://dx.doi.org/10.30659/ijocs.3.2.161-173

d) Peserta dibimbing utuk praktik membuat materi menggunakan aplikasi.

e) Peserta dibimbing untuk membuat soal/tes menggunakan aplikasi.

f) Peserta dibimbing untuk membagi hasil kepada siswa.

g) Peserta dibimbing untuk melihat response siswa.

h) Peserta dibimbing cara memberi feedback kepada siswa.

i) Peserta melakukan praktik menggunakan media (Gambar 5).
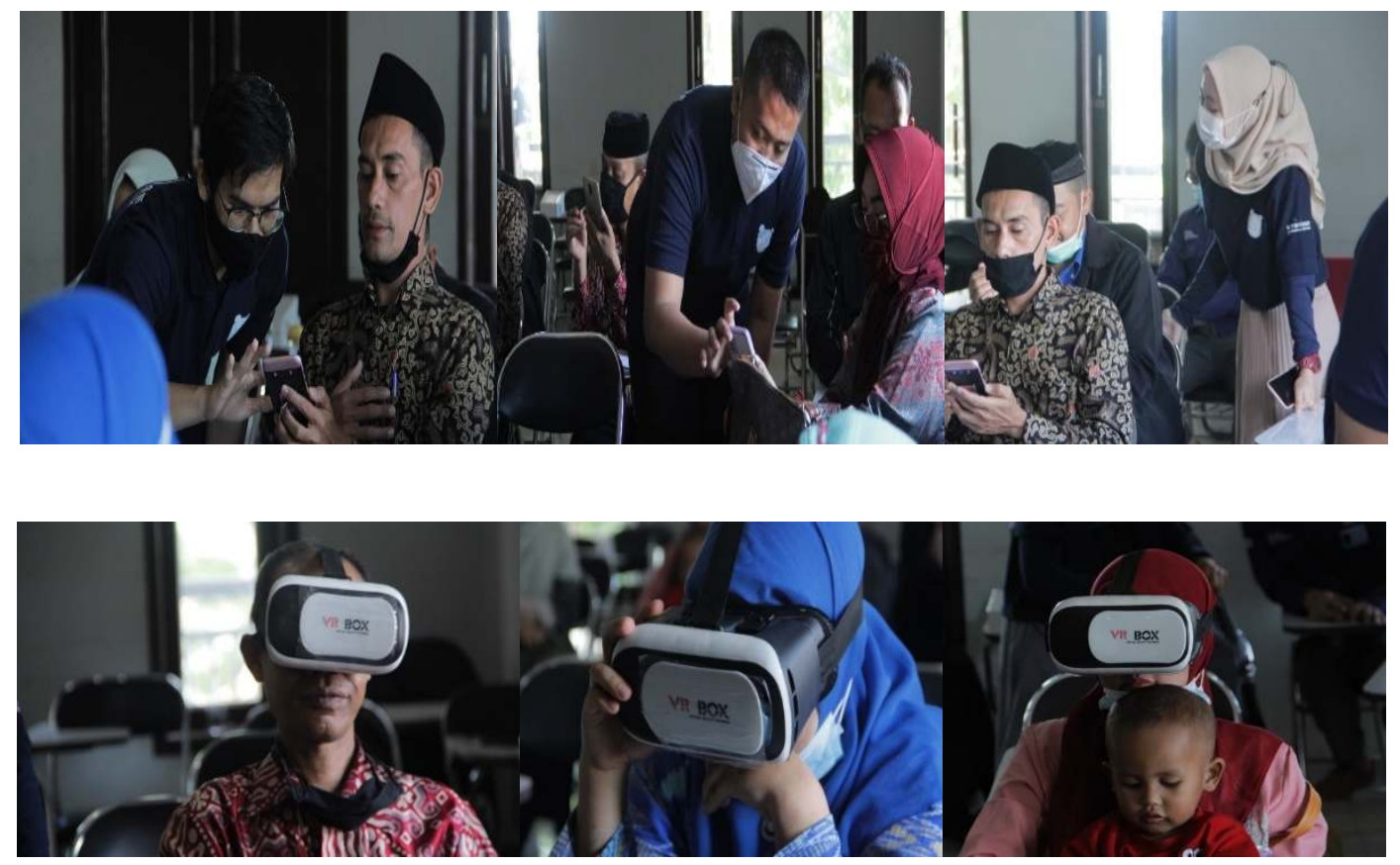

Gambar 5. Sesi Pembimbingan

\section{Sesi Evaluasi}

Setelah sesi praktik selesai, acara berlanjut ke sesi evaluasi yang dilaksanakan sebelum penutupan acara. Pada sesi ini, masing-masing peserta diminta untuk mengisi angket yang disediakan. Hasil dari angket tersebut menunjukkan respon peserta terkait pelaksanaan pelatihan. Respon tersebut menunjukkan beberapa poin penting berikut:

1. Meningkatkan literasi digital

Dari hasil angket tampak respon peserta yang menyatakan bahwa pelatihan ini sangat bermanfaat bagi peserta terutama dalam meningkatkan kemampuan penguasaan teknologi. Dalam hal ini, beberapa peserta berpendapat bahwa mereka menjadi lebih banyak mengetahui beragam aplikasi yang bisa digunakan dalam pembelajaran. Mereka juga berkesempatan untuk mempraktikkan langsung aplikasi yang diajarkan oleh pemateri. Hal ini menuntut mereka untuk mempraktikkan langsung materi yang diperoleh sehingga mereka pun diharuskan menggunakan beragam perangkat digital.

2. Memberi stimulus terhadap kreativitas guru

Respon lainnya menunjukkan bahwa pelatihan ini merupakan salah satu momen untuk merangsang para guru agar lebih kreatif selama proses pembelajaran. Kreativitas yang berkaitan dengan pelatihan ini adalah kreativitas dalam memilih media pembelajaran yang sesuai dengan tujuan pembelajaran dan materi pembelajaran yang didesain oleh guru. Dengan diberikannya contoh beragam aplikasi, maka guru menjadi lebih banyak pilihan dalam menentukan media pembelajaran. 
3. Memotivasi guru untuk meningkatkan kompetensi

Selanjutnya, sebagian besar peserta merespon positif kegiatan pelatihan ini terutama dalam hal pemberian motivasi eksternal bagi guru. Melalui kegiatan pelatihan ini, guru menjadi lebih tercerahkan terkait banyak pilihan aplikasi yang bisa digunakan selama proses pembelajaran. Hal ini menambah semangat guru untuk terus mencoba hal baru dan lebih inovatif yang diharapkan berbanding lurus dengan peningkatan kompetensi dan profesionalisme guru.

\section{KESIMPULAN}

Guru adalah "Pendidik adalah tenaga kependidikan yang berkualifikasi sebagai guru, dosen, konselor, pamong belajar, widyaiswara, tutor, instruktur, fasilitator, dan sebutan lain yang sesuai dengan kekhususannya serta berpartisipasi dalam menyelenggarakan pendidikan. Guru PAI adalah pendidikan profesional yang memiliki tugas memberi pemahaman materi agama Islam kepada peserta didik dan masyarakat. Guru PAI yang profesional setidaknya memiliki tiga misi yaitu; Misi dakwah Islam.

Guru PAI yang profesional adalah guru yang memiliki kompetensi inti guru Pendidikan Agama Islam (PAI) dijabarkan sebagai berikut: Pertama, kompetensi pedagogik. Kompetensi ini meliputi : a) penguasaan terhadap berbagai karakteristik peserta didik dari aspek fisik, moral, sosial, kultural, emosional, dan intelektual, b) penguasaan terhadap berbagai teori belajar dan prinsip-prinsip pembelajaran yang mendidik, c) menguasai kurikulum yang terkait dengan bidang pengembangan yang diampu, d) memiliki keterampilan dalam melakukan kegiatan pengembangan yang mendidik, e) dapat memanfaatkan teknologi informasi dan komunikasi untuk kepentingan penyelenggaraan kegiatan pengembangan yang mendidik, f) memfasilitasi pengembangan potensi peserta didik untuk mengaktualisasikan berbagai penguasaan teknologi.

Profesionalisme guru perlu dikembangkan secara terus menerus dan proporsional sesuai tuntutan jabatan fungsional guru. Terlebih guru-guru di madrasah, sangat perlu meningkatkan profesionalitasnya dan kreativitasnya, dalam menghadapi perkembangan ilmu pengetahuan dan tekhnologi, supaya madrasah keberadaannya di dunia modern masih diperhitungkan, karena madrasah merupakan salah satu solusi membekali peserta didik yang berimbang antara ilmu agama, dan ilmu umum. Salah satu pengembangan profesionalisme guru adalah dengan cara mengikuti pelatihan.

Pelaksanaan kegiatan pelatihan ini memiliki dua tujuan yaitu 1) untuk mengenalkan dan menggunakan beberapa media pembelajaran digital interaktif dan 2) untuk mengintegrasikan media ajar digital dan model belajar yang dapat menumbuhkan 4C yang dilaksanakan selama satu hari setara dengan 5 jam pelajaran.

Berdasarkan kegiatan pelatihan yang telah dilaksanakan maka dapat dipahami beberapa hal. Pertama, pelatihan ini efektif dalam meningkatkan pengetahuan dan memotivasi dosen untuk memahami dan melaksanakan kewajibannya tidak hanya dalam aspek pengajaran tetapi juga mulai menggeliatkan kegiatan di bidang penelitian dan pengabdian kepada masyarakat. Kedua, pelatihan ini merupakan salah satu praktik nyata pembelajaran bagi mahasiswa yang terlibat dalam kegiatan dan memberi mereka pengalaman kegiatan kemsyarakatan. Mahasiswa tidak hanya dibekali pengetahuan namun juga dibimbing untuk mengimplementasikan di masyarakat.

Ketiga, bagi guru khususnya guru PAI pelatihan ini dapat meningkatkan pengetahuan dan memotivasi guru untuk senantiasa mengembangkan kompetensinya sehingga guru dapat merancang dan menyajikan sebuah pembelajaran yang efektif dan kreatif yang mengarahkan siswa untuk memiliki kemampuan pendidikan Abad 21 yaitu kemampuan berpikir kritis, berkolaborasi, berkomunikasi dan berkreasi.

Keempat, metode yang digunakan dalam pelatihan ini menggunakan metode yang jelas dengan tahapan pelaksanaan yang efektif. Survei dan analisis kebutuhan yang dilakukan sebelum pelaksanaan pengabdian memberikan peta yang jelas tentang permasalahan yang ada di 
masyarakat sehingga pelaksanaan pelatihan ini tepat sasaran dan dan sesuai dengan apa yang dibutuhkan oleh masyarakat. Tahapan pelaksanaan juga dilakukan dengan efektif yang diawali dengan penguatan pengetahuan tentang prosionalisme guru dan bagaimana menjadi guru yang profesional. Salah satunya yaitu penguasaan teknologi. Pendampingan yang diberikan juga sangat membantu peserta dalam mengoperasikan teknologi. Sehingga peserta memiliki pengetahuan dan keterampilan menggunakan teknologi untuk menciptakan pembelajaran yang efektif dan menyenangkan.

\section{UCAPAN TERIMA KASIH}

Dalam kesempatan ini, kami mengucapkan terima kasih yang sebesarbesarnya kepada Ketua Lembaga Pengabadian Pada Masyarakat Universitas Suryakancana (UNSUR) yang telah memberikan kemudahan dalam pelaksanan pengabdian, Dekan Fakultas Keguruan dan Ilmu Pendidikan Universitas Suryakancana FKIP UNSUR yang telah memberikan dukungan moral dan finansial pada kegiatan pengabdian ini, staf dosen Program Studi Pendidikan Bahasa Inggris FKIP UNSUR yang telah membantu kelancaran pelaksanaan kegiatan pengabdian ini, Ketua KKG PAI Kecamatan Cugenang sebagai Mitra pelaksanaan kegiatan ini yang telah turut berpartisifasi aktif dalam pelaksanaan kegiatan pengabdian ini, dan seluruh panitia pelaksana kegiatan ini.

\section{DAFTAR PUSTAKA}

Amin, H. (2019). Profesionalisme Guru Pendidikan Agama Islam Di Madrasah. Jurnal Tarbiyah Islamiyah, 4(2), 1-10.

Burhanuddin, Intiana, S. R. H., Sunayu, Saharuddin, \& Rahmat, H. (2013). Pengembangan Karya Profesi Guru Melalui Pendampingan Penelitian Tindakan Kelas Bagi Guru Sekolah Dasar Di Kecamatan Sakra Barat Kabupaten Lombok Timur. Journal of Chemical Information and Modeling, 53(9), 1689-1699.

Darmadi, H. (2015). Tugas, Peran, Kompetensi, dan Tanggung Jawab Menjadi Guru Profesional. Jurnal Edukasi, 13(2), 161-174.

Dudung, A. (2010). Kompetensi Profesional Guru ( Suatu Studi Meta-Analysis Desertasi Pascasarjana UNJ ). JKKP: Jurnal Kesejahteraan Keluarga Dan Pendidikan, 05(01), 919.

Fajriana, A. W., \& Aliyah, M. A. (2019). Tantangan Guru Dalam Meningkatan Mutu Pendidikan Agama Islam di Era Melenial. Nazhruna: Jurnal Pendidikan Islam, 2(2), 246-265.

Fathurrahman, \& Muhtarom, A. (2019). Pengaruh Pembinaan Tri Dharma Perguruan Tinggi terhadap. Ilmu Pendidikan Jurnal Kajian Teori Dan Praktik Kependidikan, 4(1), 45-48.

Gunawan, Mardhia, D., Yahya, F., Kautsari, N., \& Masniadi, R. (2015). Penyuluhan Tentang Peluang Dan Tantangan Penerapan Tri Dharma Perguruan Tinggi Di Era Revolusi Industri 4.0. Penyuluhan Tentang Peluang Dan Tantangan Penerapan Tri Dharma Perguruan Tinggi Di Era Revolusi Industri 4.0, 7(9), 27-44.

Iswati, L. (2019). Pelatihan TOEIC untuk siswi-siswi Tata Busana SMK Muhammadiyah Bangunjiwo, Kasihan, Bantul, Yogyakarta. Indonesian Journal of Community Services, 1(2), 134. https://doi.org/10.30659/ijocs.1.2.134-143

Lian, B. (2019). Tanggung Jawab Tridharma Perguruan Tinggi Menjawab Kebutuhan Masyarakat. Prosiding Seminar Nasional Pendidikan Program Pascasarjana Universitas 
PGRI Palembang, 2, 999-1015.

Lubis, S. (2017). Peningkatan Profesionalisme Guru PAI Melalui Kelompok Kerja Guru ( KKG ). Jurnal Al-Thariqah, 2(2), 189-204.

Masitoh, D. (2017). Peningkatan Profesionalisme Guru Pai Melalui Program Sertifikasi Di Smp Se-Kecamatan Punggur. IAIN Metro Lampung.

Muchith, M. S. (2016). Guru PAI yang Profesional. QUALITY, 4(2), 217-235.

Nasir, M. (2013). Profesionalisme guru agama islam (sebuah upaya peningkatan mutu melalui lptk). Dinamika Ilmu, 13(2), 189-203.

Nurkholisah. (2017). Implementasi Profesionalitas Guru Pendidikan Agama Islam Paska Sertifikasi Guru Di Madrasah Tsanawiyah Negeri Kota Binjai. ANALYTICA ISLAMICA, 6(2), 95-104.

Paridi, K., Sudika, I. N., \& Burhanuddin. (2018). Penyuluhan Standardisasi Sistem Fonologi Bahasa Sumbawa. Jurnal Pendidikan Dan Pengabdian Masyarakat, 53(1), 59-65. Retrieved from http://dx.doi.org/10.1016/j.encep.2012.03.001

Sakti, B. P. (2020). Upaya Peningkatan Guru Profesional Dalam Menghadapi Pendidikan Di Era Globalisasi. Attadib Journal Of Elementary Education, 4(1), 74-83.

Sepriyanti, N. (2012). Guru Profesional adalah Kunci Mewujudkan Pendidikan Berkualitas. Jurnal Al-Ta'lim, 1(1), 66-73.

Sukri, Rusdiawan, Nawawi, \& Burhanuddin. (2018). Pemasyarakatan Standard Pendidikan Guru Di Kabupaten Lombok Utara. Jurnal Pendidikan Dan Pengabdian Masyarakat, 1(2).

Ubabuddin. (2018). Profesionalisme Guru Dalam Meningkatkan Kualitas Pendidikan Agama Islam Melalui Penilaian Kinerja Guru. AT-TUHFAH: Jurnal Keislaman, 7(2), 20-33.

Umah, A. N. U. (2015). Upaya Peningkatan Profesionalisme Guru Melalui Kegiatan Kelompok Kerja Guru Pendidikan Agama Islam Di Kecamatan Samigaluh, Kabupaten Kulon Progo. Millah, XIV(2). 